\title{
A Simple Apparatus for Measuring Cell Settling Velocity
}

\author{
Zhaowei Wang \\ Cleveland State University \\ Joanne M. Belovich \\ Cleveland State University
}

Follow this and additional works at: https://engagedscholarship.csuohio.edu/encbe_facpub

Part of the Biomedical Engineering and Bioengineering Commons

How does access to this work benefit you? Let us know!

\section{Publisher's Statement}

This is the accepted version of the following article: Zhaowei, W., \& Belovich, J. M. (2010). A simple apparatus for measuring cell settling velocity. Biotechnology Progress, 26(5), 1361-1366. doi:10.1002/btpr.432, which has been published in final form at http://onlinelibrary.wiley.com/ doi/10.1002/btpr.432/abstract

\section{Original Citation}

Zhaowei, W., \& Belovich, J. M. (2010). A simple apparatus for measuring cell settling velocity. Biotechnology Progress, 26(5), 1361-1366. doi:10.1002/btpr.432

\section{Repository Citation}

Wang, Zhaowei and Belovich, Joanne M., "A Simple Apparatus for Measuring Cell Settling Velocity" (2010). Chemical \& Biomedical Engineering Faculty Publications. 46.

https://engagedscholarship.csuohio.edu/encbe_facpub/46

This Article is brought to you for free and open access by the Chemical \& Biomedical Engineering Department at EngagedScholarship@CSU. It has been accepted for inclusion in Chemical \& Biomedical Engineering Faculty Publications by an authorized administrator of EngagedScholarship@CSU. For more information, please contact library.es@csuohio.edu. 


\title{
A Simple Apparatus for Measuring Cell Settling Velocity
}

\author{
Zhaowei Wang and Joanne M. Belovich \\ Dept. of Chemical and Biomedical Engineering, Cleveland State University, Cleveland, OH 44115
}

\section{Introduction}

Gravity settlers have been successfully applied as cell retention devices in perfusion cell cultures from the benchtop to large scale industrial applications. ${ }^{1-10}$ The capacity of an inclined gravity settler to clarify cell suspension is described in Eq. 1:

$$
S(v)=v \cdot s_{\mathrm{p}}
$$

where $S(v)$ is the volumetric flow rate of fluid clarified of particles with sedimentation velocity $v ; s_{\mathrm{p}}$ is the projection area of an inclined gravity settler, given by $w(L \sin \theta+$ $b \cos \theta): w$ is the settler width, $b$ is the separation between the two inclined surfaces, $L$ is the length of the settler, and $\theta$ is the angle of inclination of the settler from the vertical. Batt et al. and Davis et al. ${ }^{1,8}$ have successfully predicted the cell retention efficiency of gravity settlers based on theoretically calculated cell settling velocities.

The accurate determination of the viable cell sedimentation velocity is critical for controlling the operation of the gravity settler to maximize viable cell recycling, and thus viable cell concentration in the bioreactor. During long-term perfusion culture, the cell suspension is a mixture of viable and nonviable cells, and the nonviable cells have settling velocities that are less than that of the viable cells. ${ }^{1,4}$

Viable cell settling velocity can vary significantly among mammalian cell lines; for instance, the settling velocity of hybridoma cell line AB2-143.2 and CHO cell line M1-59 are $2.9 \mathrm{~cm} / \mathrm{h}$ and $1.45 \mathrm{~cm} / \mathrm{h}$, respectively. ${ }^{1,4}$ This twofold difference demonstrates the necessity of measuring this parameter for every new cell line to be used in a gravity settler/perfusion system to properly select the gravity settler with appropriate capacity.
Moreover, the settling velocity of viable cells may change substantially during the course of a long-term perfusion culture due to changes in cell size. ${ }^{11-14}$ It is thus important to measure the distinct settling velocity of the viable and nonviable cell populations periodically during a long-term perfusion culture to optimize the operation of the gravity settler in real time.

The measurement of erythrocyte sedimentation rate (ESR) has been widely used for over 50 years as a simple, standardized medical screening test. ${ }^{15-20}$ Although many modifications have been made to speedup the procedure, ${ }^{21-23}$ the basic operational principle is the same. A sample of blood is placed in a narrow tube (Westergren Tube), and after a period of time, a visible interface forms between the clarified plasma and the red blood cells. By reading the scale at the interface after a defined period of time, the sedimentation can be determined. This method assumes the red blood cells have uniform size and settling velocity; therefore, the movement of the red blood cell population is taken as the distance that the cells at the top of the tube can move in certain time. This method is not directly applicable to mammalian cell culture, because there is not a clear color difference between the cells and the clarified supernatant. For the same reason, the method used to determine plant cell settling velocity is not practical for animal cell culture. ${ }^{24}$ Even if there is a clearly identifiable interface, only the settling velocity of the smallest nonviable cells can be determined in this manner. This measurement is much less important than that of the viable cells for optimizing the gravity settler operation.

Particle image velocimetry (PIV) ${ }^{25}$ has been used primarily for directly measuring the settling velocity of individual particles. Despite the complexity of this process, it cannot distinguish between viable and nonviable cell settling velocity. Another method, the "Owen Tube," is a 1-L column used for determining the settling velocity of suspended particulate matter in natural body water. ${ }^{26-28}$ Periodic samples 

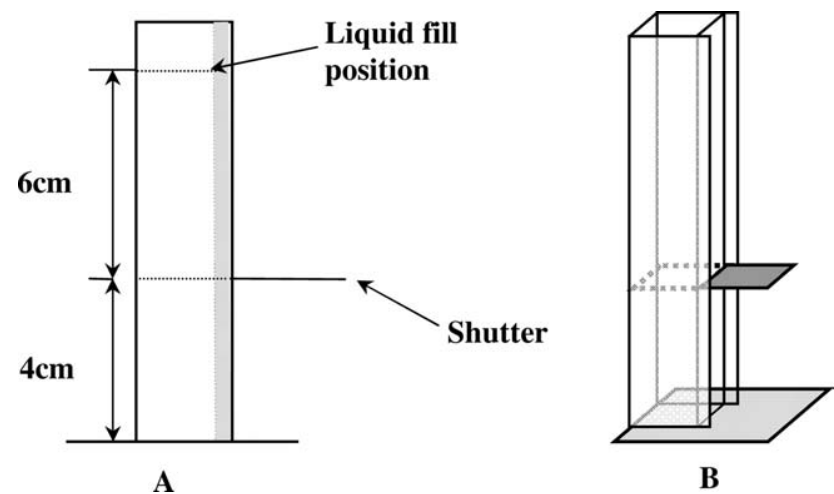

Figure 1. Schematic of the settling column.

(A) Side view. (B) 3-D view.

are removed from the bottom of the Owen Tube, and the dry weight measurement is used to determine the settling velocity. This method is not accurate for small sample amounts, the presence of cell debris would contribute to measurement error, and the process cannot distinguish the viability of the cells.

Stokes' law can be used to theoretically calculate the settling velocity of particles in fluid when the Reynolds number is less than 0.2 , given by:

$$
v=\frac{g d_{\mathrm{p}}^{2}\left(\rho_{\mathrm{p}}-\rho\right)}{18 \mu}
$$

where $d_{\mathrm{p}}=$ particle diameter, $\mu=$ fluid viscosity, $\rho_{\mathrm{p}}=$ density of solid particle, $\rho=$ density of carrying fluid, and $g=$ acceleration due to gravity. The particle diameter is normally determined by means of a Particle Size Analyzer (Particle Data, Inc.) or Coulter Multisizer (Beckman Coulter, Fullerton, CA). The particle density is measured using neutral buoyancy measurement or density gradient partitioning methods. A glass capillary viscometer can be used to determine the fluid viscosity. The fluid density is easily determined from weight and volume measurements. Using this procedure, the settling velocity of viable and nonviable hybridoma and CHO cells have been determined. ${ }^{1,4}$ This method is not practical for routine measurements during long-term perfusion culture because multiple measurements are needed for a single settling velocity determination, which is time consuming and increases the potential for measurement error.

We have developed a simple, inexpensive, and rapid method for measuring settling velocity of both viable and nonviable cells in a mixed population, based on a modification of the Westergren Tube. The accuracy of this method is demonstrated using polystyrene particles with known physical properties. The method is then used to measure the settling velocity of three different hybridoma cell lines.

\section{Materials and Methods}

\section{Settling column}

A schematic of the settling device is shown in Figure 1. The device consists of a rectangular settling column made of 2.4-mm glass plate, with an internal width of $1.4 \mathrm{~cm}$, internal length of $2.0 \mathrm{~cm}$, and height of $11.5 \mathrm{~cm}$. There is a 0.6 $\mathrm{mm}$ wide slot in the narrow side of the column, at a distance of $4 \mathrm{~cm}$ from the bottom. At the same height, as the slot is a $0.6-\mathrm{mm}$ wide and $0.5-\mathrm{mm}$ deep groove on the other three sides of glasses. The groove is filled with silicone glue (General Electric). The edge of the plate glass at the slot is also coated with the silicone glue. A shutter is made of $0.5-\mathrm{mm}$ thick and $4.5-\mathrm{cm}$ long stainless steel plate, which is slightly wider than the width of the slot. The groove in the glass works as a track to guide the shutter through the slot. The function of the cured silicone glue is to help seal the contact between the shutter and glass surface. When conducting the settling velocity measurement, high vacuum grease was also applied to the interface between the glass plate and the shutter to help seal the contacts. When the shutter is pushed into the column, the lower part of the column can be totally closed. The settling column is exactly perpendicular to the supporting $7 \mathrm{~cm} \times 7 \mathrm{~cm}$ glass plate, to which it is glued. The device should be located on a leveled horizontal surface so the settling column is strictly vertical.

\section{Standard particles}

Monodisperse standard polystyrene particles (Sigma, St. Louis, MO) with $15 \mu \mathrm{m}$ diameter (standard deviation $<0.2$ $\mu \mathrm{m})$ and $1.05 \mathrm{~g} / \mathrm{cm}^{3}$ density were used to verify the reliability of the device. The particles were suspended in DI water supplemented with $0.1 \%$ Triton X-100 (Sigma, St. Louis, $\mathrm{MO}$ ), which helps prevent the particles from aggregating. The viscosity of the solution (without the particles) at $28^{\circ} \mathrm{C}$ is 0.0084 poise, as measured using a size 25 glass capillary viscometer (Cannon Instrument Co., State College, PA). The density of the fluid is $0.996 \mathrm{~g} / \mathrm{cm}^{3}$. The concentration of the particle suspension is $1.8 \times 10^{5}$ particles $/ \mathrm{mL}$, resulting in $0.03 \%$ volume fraction. All the particle settling velocity measurements were conducted in a $28^{\circ} \mathrm{C}$ incubator.

\section{Cell lines and cell culture}

Three hybridoma cell lines, HB-159 (ATCC), 9E10 (ATCC), and R73 (Cleveland Clinic Foundation, Cleveland, $\mathrm{OH})$, were tested with the settling column. All cells were cultured with BD Cell ${ }^{\mathrm{TM}}$ Mab serum free medium (BD Biosciences - Advanced Bioprocessing, Sparks, MD) and maintained in $250 \mathrm{~mL}$ T-flasks in a $37^{\circ} \mathrm{C}$ incubator at $5 \%$ carbon dioxide. Cell settling velocity measurements were conducted with cells in the exponential growth phase, in the second day after inoculation, and with cells in death phase, in the fifth day after inoculation, as the cell concentrations were around $1 \times 10^{6}$ cells $/ \mathrm{mL}$. All cell settling velocity measurements were conducted in the $37^{\circ} \mathrm{C}$ incubator. Cell size distribution measurements of HB-159 were conducted with cells cultured $2,6,9,13$, and 17 days after inoculation. The nonviable cell settling velocity was measured only when the population viability was lower than $70 \%$ to obtain enough nonviable cells to be counted accurately using a hemocytometer.

\section{Particles and cell counting}

The polystyrene particles were counted using a Z2 Coulter Counter (Beckman Coulter, Fullerton, CA) equipped with a $70 \mu \mathrm{m}$ ampoule aperture tube. The lower threshold was set at $14 \mathrm{um}$ and higher threshold was $16 \mathrm{um}$. The Coulter Counter was also used to determine the cell size distribution of the HB-159 cells. The cell concentration and viability were measured using a hemocytometer and trypan blue exclusion method. More than 1,000 viable cells were counted for each sample. 


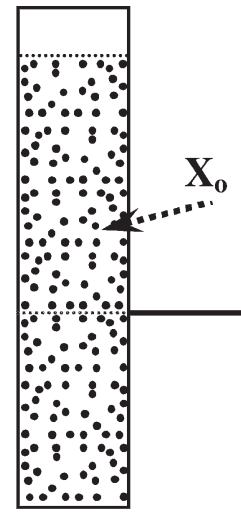

A

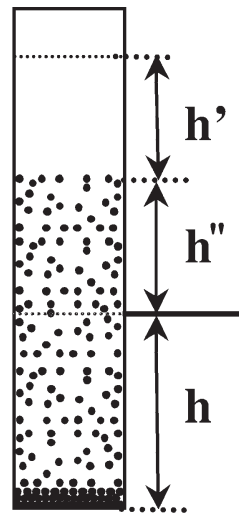

B

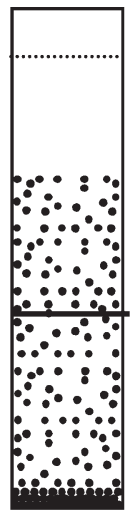

C

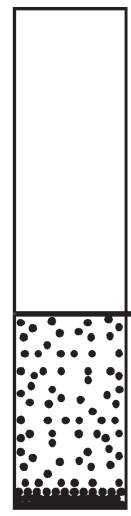

D

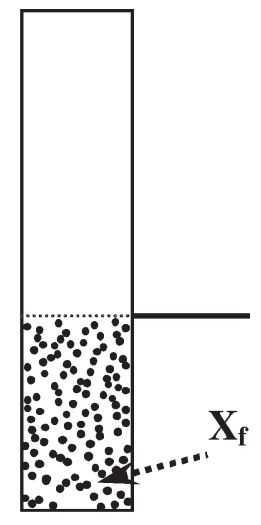

E

Figure 2. Protocol of particle settling velocity measurement using the settling column.

A: The column is filled with well-mixed monodisperse particle suspension with known concentration $X_{\mathrm{o}}$. B: Particles moved downward $h^{\prime}$ distance in $1 \mathrm{~h}$. C: The column is separated into two parts by pushing in the shutter to stop particles from moving into the lower part of the column. D: The particle suspension above the shutter is removed. E: The particles settled at the bottom of the column are resuspended and the suspension is well mixed, and then sampled and the particle concentration measured.

\section{Settling velocity measurement procedure and analysis}

A sample containing $28 \mathrm{~mL}$ of the well-mixed monodisperse particle suspension, with concentration given by $X_{\mathrm{o}}$, is added to the settling column (Figure 2A) with the shutter open. Assuming uniform particle density and diameter, the particles settle down at the same rate, traveling a distance $h^{\prime}$ over the settling time period $t$ (Figure 2B). The particle settling velocity is given by:

$$
v=\frac{h^{\prime}}{t}
$$

The volume of the column vacated by the particles is given by:

$$
V^{\prime}=h \cdot A
$$

where $A$ is the cross section area of the settling column. Similarly, the volume below the shutter $(V)$ and the volume between the shutter and the interface $\left(V^{\prime \prime}\right)$ are given by:

$$
\begin{gathered}
V=h \cdot A \\
V^{\prime \prime}=h^{\prime \prime} \cdot A
\end{gathered}
$$

At time $=t$, the shutter is closed (Figure 2C). The particle suspension above the shutter is first removed (Figure 2D). The settled particles on the bottom of the column are then resuspended and thoroughly mixed with the remaining particle suspension below the shutter, yielding the concentration $X_{\mathrm{f}}$. Mass is conserved between time $=0$ and time $=t$, yielding:

$$
X_{\mathrm{o}}\left(V^{\prime}+V^{\prime \prime}+V\right)=X_{\mathrm{o}} V^{\prime \prime}+X_{\mathrm{f}} V
$$

Combining Eqs. 3-6 yields:

$$
v=\frac{h\left(X_{\mathrm{f}}-X_{\mathrm{o}}\right)}{t X_{\mathrm{o}}}
$$

The distance $h$ is fixed by the device design and $X_{\mathrm{o}}$ is known from the sample preparation. The experiment is conducted for a known amount of time $t$, such that the particle interface remains above the shutter position during the time $t$. Therefore, the only measurement needed is that of the particle concentration in the lower volume, $X_{\mathrm{f}}$.

A cell population containing a mixture of viable and nonviable cells can analyzed with this same approach. Equations 3-7 can be written for the viable cells in the sample, and separately, for the nonviable cells. The viable and nonviable cell counts in the volume $V$ can both be measured by means of the hemocytometer. Thus, Eq. 7 can be applied to each cell concentration, $X_{\mathrm{f}}$, to calculate the settling velocity of each cell population (viable and nonviable).

\section{Results and Discussion}

\section{Theoretical calculation of the particle settling velocity}

The settling velocity of $15-\mu \mathrm{m}$ polystyrene particles at $28^{\circ} \mathrm{C}$ was calculated using Eq. 2 and the data in the Methods section to be $2.81 \mathrm{~cm} / \mathrm{h}$. To confirm the applicability of Stokes' law to this system, the Reynolds number was calculated using:

$$
R e=\rho_{\mathrm{p}} d_{\mathrm{p}} v / \mu
$$

The calculated $R e$ number is 0.0014 , indicating that the settling velocity is indeed governed by Stokes' law.

The corrected settling velocity can be calculated taking into account particle concentration and wall effects by means of ${ }^{29}$ :

$$
v_{\mathrm{ts}}=v(1-\mathrm{c})^{n} /(1+2.1 \beta)
$$

where $v_{\mathrm{ts}}$ is the corrected settling velocity, $v$ is the settling velocity of a single particle calculated from Stokes' law, $c$ is the volume fraction of the particles in the fluid, $n$ is a function of Reynolds number, equal to 4.65 when Reynolds number is less than 0.3 , and $\beta$ is the ratio of particle diameter to vessel diameter. The hydraulic diameter is commonly used to calculate the equivalent diameter when handling flow in noncircular channels, defined as:

$$
d_{\mathrm{h}}=\frac{4 A}{U}
$$

where $A$ is the area of the cross section of the rectangular channel and $U$ is the wetted perimeter of the cross section. The hydraulic diameter of the settling column used here is $1.47 \mathrm{~cm}$. 

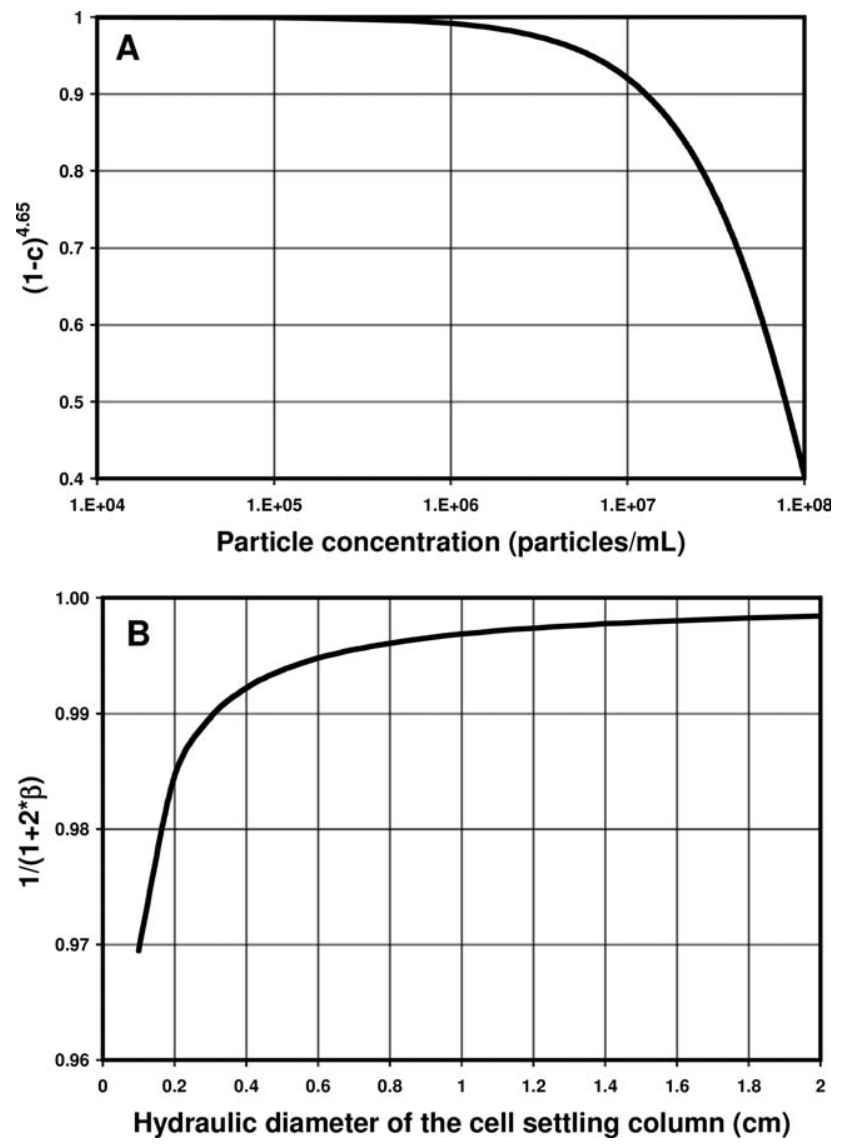

Figure 3. Calculation of concentration effect and wall effect based on polystyrene particles with $15 \mu \mathrm{m}$ diameter.

(A) Concentration effect. (B) Wall effect.

The corrected theoretical settling velocity for the polystyrene particles, calculated using Eq. 9 with concentration of $1.8 \times 10^{5}$ particles $/ \mathrm{mL}$ (volume fraction of $0.03 \%$ ), is 2.80 $\mathrm{cm} / \mathrm{h}$. The difference between the calculated value using Stokes' law and the corrected one is less than $0.4 \%$, indicating that the effects of concentration and the wall are negligible. At concentrations greater than $1 \times 10^{7}$ particles $/ \mathrm{mL}$, the concentration effect on settling velocity increases sharply (Figure 3A). Without compensation for the concentration effect, at cell concentrations of $5 \times 10^{7}$ cells $/ \mathrm{mL}$ (expected during perfusion culture), the Stokes' law settling velocity has over $30 \%$ deviation from the actual settling velocity. This large deviation demonstrates the advantage of a direct measurement of this property using the settling column, rather than a theoretical calculation using Stokes' law. As shown in Figure 3B, the wall effect is still negligible even at half the hydraulic diameter of the current settling column prototype. This result indicates that the minimum cell suspension volume needed for use in the settling column can be reduced to less than $10 \mathrm{~mL}$ with no material impact on the accuracy of the measurement.

\section{Standard polystyrene particle settling velocity measurement}

The settling velocity of the polystyrene particles, measured using the settling column, is $2.70 \pm 0.08 \mathrm{~cm} / \mathrm{h}$ (Figure 4 ). This value is $3.6 \%$ smaller than the theoretical value, corrected for wall and concentration effects. This small deviation is most likely caused by particle inertial effects, which are difficult to predict. ${ }^{25,30-34}$ It is almost impossible to

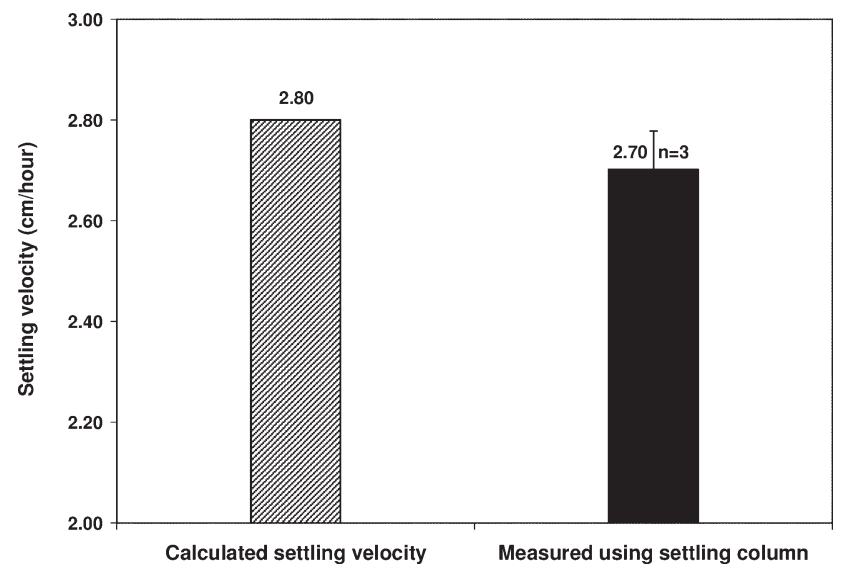

Figure 4. Comparison of the settling velocities of $15 \mu \mathrm{m}$ polystyrene particles, calculated using Stokes' law and the measurements described in the Methods section (left) and measured using the settling column (right).

The error bar indicates the standard deviation and $n$ is the number of repetitions. Comparison of results using the students' $t$ test gives a $p$-value $=0.09$.

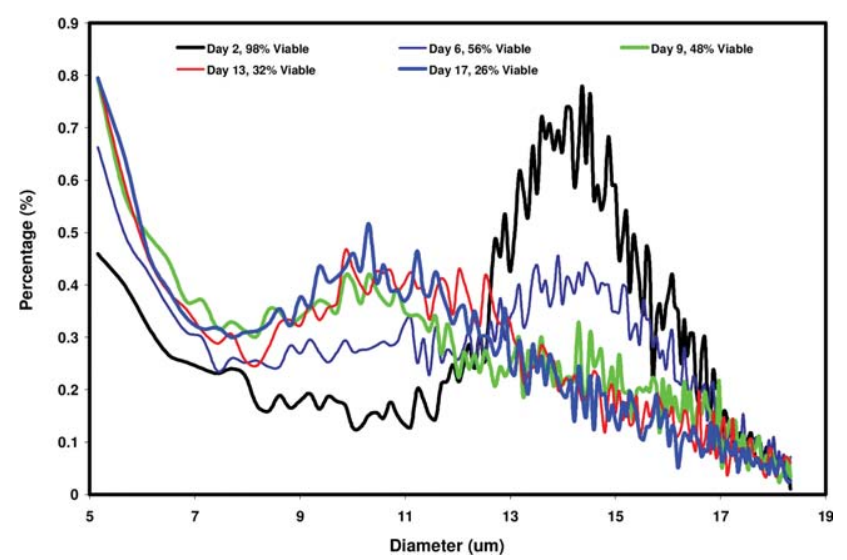

Figure 5. Size distribution histograms of HB-159 hybridoma cells cultured in $250 \mathrm{~m} l \mathrm{~T}$-flask.

Percentage is based on cell number.

totally avoid swirling or convective motion of the particle suspension. Particle inertia influences the settling velocity at both the microscale and macroscale. To minimize the inertial effect by avoiding convection caused by a temperature difference, the settling column and particle suspension should be at the same temperature before the suspension is added to the column. Convection can also be reduced by the slow addition of the suspension to the column.

\section{Hybridoma cell settling velocity measurements}

The size distributions of the HB-159 hybridoma cell line at different lengths of time in culture are shown in Figure 5. Two peaks are evident at diameters of $10 \mu \mathrm{m}$ and $14.5 \mu \mathrm{m}$. The percentage of cells with the lower diameter increased with decreasing viability. Two peaks are evident at diameters of $10 \mu \mathrm{m}$ for cultures aged 13 days and at diameters of 14.5 $\mu \mathrm{m}$ for cultures aged 2 days. These results are in agreement with results reported by Searles et al. ${ }^{4}$ in which the mean size of nonviable cells is significantly smaller than that of the viable cells. Not only are nonviable cells smaller than viable cells but also the nonviable cells decrease in diameter as the population viability decreases. ${ }^{4}$ It has also been 
Table 1. Comparison of cell settling velocities

\begin{tabular}{lccc}
\hline & & \multicolumn{2}{c}{$\begin{array}{c}\text { Settling Velocity } \\
(\mathrm{cm} / \mathrm{h})\end{array}$} \\
\cline { 3 - 4 } Cell Line & Viability $(\%)$ & Viable & Nonviable \\
\hline Hybridoma HB-159 & 94 & 3.5 & N/A \\
Hybridoma R73 & 64 & 2.8 & 1.7 \\
Hybridoma 9E10 & 96 & 1.8 & N/A \\
Hybridoma AB2-143.2 & 65 & 0.9 & 0.6 \\
CHO M1-59 & 97 & 2.6 & N/A \\
& 65 & 1.8 & 0.9 \\
& N/A & 2.9 & 1.1 \\
& N/A & 1.4 & 0.86
\end{tabular}

The settling velocities of the HB-159, R73, and 9E10 cell lines were achieved using the settling column. The results for the hybridoma AB2143.2 and CHO M1-59 cell lines were reported in the literature.

reported that viable cell diameter increases over $20 \%$ when the cells progress from lag phase to exponential phase. ${ }^{35,36}$

Table 1 shows the settling velocities of three hybridoma cell lines measured using the settling column along with settling velocities of two cell lines reported in the literature. ${ }^{1,4}$ The variation in settling velocities of the three hybridoma cell lines is significant, with a twofold variation between the HB-159 and the R73. These measurements are similar to values reported for a hybridoma cell line and a $\mathrm{CHO}$ cell line, obtained using Stokes' law. ${ }^{1,4}$ The twofold variation in settling velocities indicates that the cell line with the lower velocity will need a gravity settler that is double in size to achieve the same cell retention capacity as that of the faster settling cell line. This confirms the necessity of measuring the settling velocity before selecting the gravity settler and starting the perfusion culture.

The settling velocities of the nonviable cells are 30-50\% lower than the corresponding viable settling velocity (Table 1). This difference is the basis of preferential removal of nonviable cells using gravity settler in perfusion culture bioreactors.

Table 1 also shows that even for the same cell line, the viable cell settling velocity decreases significantly, up to $50 \%$, when viability of the cell suspension decreases from $97 \%$ to $65 \%$. Because a lowered viability is a normal outcome during long-term perfusion culture, this result indicates that the minimum capacity of the gravity settler would need to be doubled to maintain the cell retention efficiency throughout the culture period. Otherwise, loss of viable cells would likely occur. Therefore, it is necessary to measure the cell settling velocity periodically during the perfusion culture especially when the cell viability drops significantly. ${ }^{37}$

\section{Analysis of the settling column method for a heterogeneous population of particles}

An actual cell sample contains a distribution of cell sizes, as shown in Figure 5, and thus is expected to have a distribution of settling velocities. The interpretation of the settling velocity, as measured with the method described above, for a nonuniform population of particles, is presented here.

Suppose the particle mixture has distribution of diameters, where each diameter is represented by $d_{i}$, with $i=1, \ldots n$, where $n$ is the number of different discrete particle sizes. The sample concentration, $X_{\mathrm{o}}$, can be represented by:

$$
X_{\mathrm{o}}=\sum_{1}^{n} f_{i, \mathrm{o}}
$$

where $x_{i, \mathrm{o}}$ is the concentration of particles in the mixture with diameter $d_{i}$. The analysis presented in Eqs. 3-7 for a homogeneous population of particles can be written for each particle of diameter $d_{i}$, i.e.:

$$
v_{i}=\frac{h\left(x_{i, \mathrm{f}}-x_{i, \mathrm{o}}\right)}{x_{i, \mathrm{o}} t}
$$

Let $\bar{v}$ be the number average settling velocity of the population, defined by:

$$
\bar{v}=\frac{1}{X_{\mathrm{o}}} \sum_{i=1}^{n} v_{i} x_{i, \mathrm{o}}
$$

Substitution of Eq. 12 into Eq. 13, and rearranging, yields:

$$
\left.\bar{v}=\frac{h}{X_{\mathrm{o}} t} \quad \sum_{i=1}^{n} x_{i, \mathrm{f}}-\sum_{i=1}^{n} x_{i, \mathrm{o}}\right)(
$$

Substitution of Eq. 11 for the initial concentration, $X_{\mathrm{o}}$, and the equivalent expression for the final concentration, $X_{\mathrm{f}}$, yields:

$$
\bar{v}=\frac{h}{X_{\mathrm{o}}}\left(X_{\mathrm{f}}-X_{\mathrm{o}}\right)
$$

The right hand sides of Eqs. 15 and 7 are identical; thus the measured population settling velocity, $v$, is identical to the number average velocity, $\bar{v}$.

\section{Conclusions}

The settling column described here provides an inexpensive, rapid, and accurate method for determining cell settling velocities and that can distinguish the settling velocities of viable and nonviable cells. The method was validated using polystyrene particles with known physical properties, and resulted in less than $4 \%$ error compared with the theoretical value obtained using Stokes' law.

This method transfers the cell settling velocity measurement into a cell counting procedure, which is simpler to obtain than the multiple measurements needed for a Stokes' law calculation. This method can be further simplified by use of automated cell counting equipment that can distinguish between viable and nonviable cells ${ }^{2,38,39}$ rather than the traditional hemocytometer. Furthermore, Stokes' law assumes that the cells are perfectly spherical, whereas the settling column can be used to measure the true settling velocity of irregularly shaped particles or cells. The settling column presented here was designed for mammalian cells with expected settling velocities less than $6 \mathrm{~cm} / \mathrm{h}$. The settling velocity of bigger particles, which settle much faster than the cells tested here, can be measured simply by increasing the height of the column without increasing the distance between the shutter and bottom.

The settling velocity differs significantly among cell lines and it changes substantially when cell viability drops for same cell line. The cell settling velocity measurement should thus be performed routinely for each cell line both before and during the perfusion culture when a gravity settler is used for cell retention. In this way, a gravity settler with enough capacity can be selected a priori to maximize viable cell retention efficiency. Furthermore, the time dependency of the cell size and thus the settling velocity indicates that a 
gravity settler with real-time adjustable capacity is preferred for optimal cell retention.

\section{Acknowledgments}

The authors thankfully acknowledge BD Biosciences Advanced Bioprocessing for providing BD Cell ${ }^{\mathrm{TM}}$ Mab serum free medium. They also thank Dr. Maciej Zborowski and Mr. Lee R. Moore for providing access to and assistance with the Coulter Counter Z2. Funding was provided by the State of Ohio and the Cleveland State University Doctoral Dissertation Research Expense Award.

\section{Literature Cited}

1. Batt B, Davis R, Kompala D. Inclined sedimentation for selective retention of viable hybridomas in a continuous suspension bioreactor. Biotechnol Prog. 1990;6:458-464.

2. Choo CY, Tian Y, Kim WS, Blatter E, Conary J, Brady CP. High-level production of a monoclonal antibody in murine myeloma cells by perfusion culture using a gravity settler. Biotechnol Prog. 2007;23:225-231.

3. Hülscner M, Scheibler U, Onken U. Selective recycle of viable animal cells by coupling of airlift reactor cell settler. Biotechnol Bioeng. 1992;39:442-446.

4. Searles J, Todd P, Kompala DS. Viable cell recycle with an inclined settler in the perfusion culture of suspended recombinant chinese hamster ovary cells. Biotechnol Prog. 1994;10:198-206.

5. Wen Z-Y, Teng X-W, Chen F. A novel perfusion system for animal cell cultures by two step sequential sedimentation. $J$ Biotechnol. 2000;79:1-11.

6. Shackel I, Bass A, Brewer A, Brown P, Tsao M, Chang L. Comparison of manufacture technologies for rav12 monoclonal antibody in production medium containing no animal derived proteins. In: Smith R, ed. Cell Technology for Cell Products. Dordrecht, The Netherlands: Springer Netherlands; 2007: 761-763.

7. Maia ABRA, Nelson DL. Application of gravitational sedimentation to efficient cellular recycling in continuous alcoholic fermentation. Biotechnol Bioeng. 1993;41:361-369.

8. Davis RH, Lee CY, Batt BC, Kompala DS. Cell separations using differential sedimentation in inclined settlers. In: Kompala DS, Todd P, editors. Cell Separation Science and Technology. Washington, DC: American Chemical Society; 1991:113-127.

9. Nottorf T, Hoera W, Buentemeyer H, Siwiora-Brenke S, Loa A, Lehmann J. Production of human growth hormone in a mammalian cell high density perfusion process. In: Smith R, ed. Cell Technology for Cell Products. Dordrecht, The Netherlands: Springer Netherlands; 2007:789-793.

10. Kompala DS, Ozturk SS. Optimization of high cell density perfusion bioreactors. In: Ozturk SS, Wei-Shou H, editors. Cell Culture Technology for Pharmaceutical and Cell-Based Therapies. New York: Taylor \& Francis; 2006:387-416.

11. Al-Rubeai M, Chalder S, Bird R, Emery AN. Cell cycle, cell size and mitochondrial activity of hybridoma cells during batch cultivation. Cytotechnology. 1991;7:179-186.

12. Frame KK, Hu W-S. Cell volume measurement as an estimation of mammalian cell biomass. Biotechnol Bioeng. 1990;36:191-197.

13. Goebel NK, Kuehn R, Flickinger MC. Methods for determination of growth-rate-dependent changes in hybridoma volume, shape and surface structure during continuous recycle. Cytotechnology. 1990;4:45-57.

14. Martens DE, de Gooijer CD, van der Velden-de Groot CAM, Beuvery EC, Tramper J. Effect of dilution rate on growth, productivity, cell cycle and size, and shear sensitivity of a hybridoma cell in a continuous culture. Biotechnol Bioeng. 1993;41:429-439.

15. Mönig H, Marquardt D, Arendt T, Kloehn S. Limited value of elevated erythrocyte sedimentation rate as an indicator of malignancy. Fam Pract. 2002;19:436-438.
16. International Council for Standardization in Haematology (Expert Panel on Blood Rheology). ICSH recommendations for measurement of erythrocyte sedimentation rate. J Clin Pathol. 1993;46:198-203.

17. Woodland NB, Cordatos K, Hung WT, Reuben A, Holley L. Erythrocyte sedimentation in columns and the significance of ESR. Biorheology. 1996;33:477-488.

18. Rabjohn L, Roberts K, Troiano M, Schoenhaus H. Diagnostic and prognostic value of erythrocyte sedimentation rate in contiguous osteomyelitis of the foot and ankle. J Foot Ankle Surg. 2007;46:230-237.

19. Olshaker JS, Jerrard DA. The erythrocyte sedimentation rate. J Emerg Med. 1997;15:869-874.

20. Erikssen G, Liestol K, Bjonholt H, Stormorken H, Thaulow E, Erikssen J. Erythrocyte sedimentation rate: a possible marker of atherosclerosis and a strong predictor of coronary heart disease mortality. Eur Heart J. 2000;21:1614-1620.

21. Drucker KG. Sedimentation rate centrifuge and method determining sedimentation rate. US Patent 3,199,775, 1965.

22. Winkelman JW, Tanasijevic MJ, Bennett M. Method and apparatus for determining erythrocyte sedimentation rate and hematocrit. US Patent 6,506,606, January 14, 2003.

23. Bull BS. Method and apparatus for rapid determination of blood sedimentation rate. US Patent 5,594,164, January 14, 1997.

24. De Dobbeleer C, Cloutier M, Fouilland M, Legros R, Jolicoeur M. A high-rate perfusion bioreactor for plant cells. Biotechnol Bioeng. 2006;95:1126-1137.

25. Guazzelli É. Evolution of particle-velocity correlations in sedimentation. Phys Fluids. 2001;13:1537-1540.

26. Dearnaley MP. Direct measurements of settling velocities in the owen tube: a comparison with gravimetric analysis. J Sea Res. 1996;36:41-47.

27. Wolfstein K. Fractionation and measurements of settling velocities of suspended matter using an owen tube. J Sea Res. 1996;36:147-152.

28. Puls W, Kühl H. Settling velocity determination using the BIGDAN settling tube and the Owen settling tube. J Sea Res. 1996;36:119-125.

29. Sakiadis BC. Fluid and particle mechamics. In: Perry RH, Green DW, Maloney JO, editors. Perry's Chemical Engineers' Handbook, 6th ed. New York: McGraw-Hill; 1984:5-63-5-68.

30. Bernard-Michel G, Monavon A, Lhuillier D, Abdo D, Simon H. Particle velocity fluctuations and correlation lengths in dilute sedimenting suspensions. Phys Fluids. 2002;14:2339-2349.

31. Peysson Y, Guazzelli É. An experimental investigation of the intrinsic convection in a sedimenting suspension. Phys Fluids. 1998;10:44-54.

32. Segrè PN, Herbolzheimer E, Chaikin PM. Long-range correlations in sedimentation. Phys Rev Lett. 1997;79:2574-2577.

33. Sutterby JL. Falling sphere viscometry. I. Wall and inertial corrections to stokes' law in long tubes. J Rheol. 1973;17:559-573.

34. Tee S-Y, Mucha PJ, Cipelletti L, Manley S, Brenner MP, Segre PN, Weitz DA. Nonuniversal velocity fluctuations of sedimenting particles. Phys Rev Lett. 2002;89:054501-1-054501-4.

35. Seewöster T, Lehmann J. Cell size distribution as a parameter for the predetermination of exponential growth during repeated batch cultivation of CHO cells. Biotechnol Bioeng. 1997;55:793-797.

36. Lloyd DR, Holmes P, Jackson LP, Emery AN, Al-Rubeai M. Relationship between cell size, cell cycle and specific recombinant protein productivity. Cytotechnology. 2000;34:59-70.

37. Thompson K, Wilson J. Particle settler for use in cell culture. US Patent 5,817,505, 1998.

38. Shah D, Naciri M, Clee P, Al-Rubeai M. NucleoCounter-an efficient technique for the determination of cell number and viability in animal cell culture processes. Cytotechnology. 2006;51:39-44.

39. Tang YJ, Ohashi R, Hamel JFP. Perfusion culture of hybridoma cells for hyperproduction of $\mathrm{IgG}_{2 \mathrm{a}}$ monoclonal antibody in a wave bioreactor-perfusion culture system. Biotechnol Prog. 2007;23:255-264. 